\title{
Knowledge and Attitude for Medical Students towards COVID-19
}

\author{
Arash Ranjbar Roghani ${ }^{1}$, Reza Nemati ${ }^{2}$, Yeganeh Fathi ${ }^{3}$, Saina Sheikhnavaz Jahed ${ }^{4}$, \\ Faramarz Ajri Khamsloo ${ }^{5}$, Mehdi Ajri Khamslou ${ }^{6}$
}

\begin{abstract}
Background \& Aim: COVID-19, as an emerging infectious disease, affects the whole world. The causative agent for the disease is coronavirus acute respiratory syndrome 2 (SARS-CoV-2) and typical symptoms of the disease include fever, cough, and shortness of breath. Also, muscle pain, sputum production, sore throat, lack of taste and red eyes are among the less common symptoms. In severe cases, the disease can cause severe respiratory failure and even death. COVID-19 is transmitted from sick people to healthy people through respiratory droplets. Disease spread can be prevented by washing hands and other hygiene measures.

The rate of transmission and prevalence for the disease is higher than other infectious diseases, however, the main point in controlling the disease is the knowledge and attitude of the community towards Corona disease, which can play a key role in controlling the disease and reduce the increasing trend. It is very important to pay attention to the attitude and awareness of people involved in patient care. According to the literature review, no study has been conducted on the knowledge and attitude for medical students towards COVID-19, therefore, the current research was conducted to determine the attitude and knowledge of medical students across the country about COVID-19.

Materail \& Methods: The study was performed as descriptive cross-sectional. Data were collected through a virtual self-administered questionnaire. 420 medical students in the country participated in this study by voluntary sampling from April 20 to May 6, 2016. The final data was obtained by removing $10 \%$ of the questionnaires due to incomplete filling of 381 samples. A researcher-made questionnaire was used to collect information. The questionnaire included three sections: demographic characteristics, attitude and knowledge about COVID-19. The first part of the questionnaire contained questions related to demographic characteristics including age, gender, degree, field of study, semester, type of residence and university.

The second part, consisting of 16 phrases, was set to determine how students' attitudes toward COVID-19 disease' is based on the Likert scale of five options "totally disagree, disagree, have no opinion, agree, strongly agree" and were considered for each phrase a score of 1 to 5. The awareness section consisted of 4 dimensions (nature of disease, disease transmission, care and prevention, diagnosis and treatment) in the form of three options "yes and no and I do not know" that 1 positive score was applied for each correct answer. Content and face validity were used to determine the validity of the questionnaire. The opinion of 7 faculty members in the university about the questionnaire was obtained and their corrective opinions were applied in the questionnaire. The reliability of the attitude questionnaire with Cronbach's alpha coefficient was 0.85 and the reliability of the knowledge questionnaire with Kuder Richardson coefficient was 0.86 .

Data analysis was performed by one-way ANOVA, Pearson correlation coefficient and independent t-test with SPSS software version 16. Also, the significance level in the research was considered 0.05. Participants had full authority to complete the virtual questionnaire and data were collected anonymously.

Results: Out of 381 samples, $252(66.1 \%)$ were female students. The age range of students was 16 to 37 years and $51.1 \%$ of them belonged to the age group of $21-25$ years. 18 people (4.7\%) in associate degree, 222 people

\footnotetext{
1. Students Research Committee, School of Nursing and Midwifery, Ardabil University of Medical Sciences, Ardabil, Iran

${ }^{2}$. Students Research Committee, School of Nursing and Midwifery, Ardabil University of Medical Sciences, Ardabil, Iran

3. Students Research Committee, School of Nursing and Midwifery, Ardabil University of Medical Sciences, Ardabil, Iran

${ }^{4}$. Students Research Committee, School of Nursing and Midwifery, Ardabil University of Medical Sciences, Ardabil, Iran

5. Pediatrics Department, School of Medicine, Ardabil University of Medical Sciences, Ardabil, Iran

${ }^{6}$. Department of Intensive Care, School of Nursing and Midwifery, Ardabil University of Medical Sciences, Ardabil, Iran (Corresponding Author) Tel: 09148396994 Email: ajri@arums.ac.ir
} 
$(58.3 \%)$ in bachelor degree, 8 people $(2.1 \%)$ in master degree and 133 people $(34.9 \%)$ were studying in professional doctoral degree. 271 students $(71.1 \%)$ were students of $1-4$ semesters and 93 students $(24.4 \%)$ of them were studying in 5-8 semesters. 112 students $(29.4 \%)$ were studying in medicine, $129(33.9 \%)$ were studying in nursing and $115(30.2 \%)$ were studying in paramedical fields. Also, 57.5\% of the students were natives and $96.9 \%$ of the students had no work experience in the corona sector and $83.5 \%$ of the students did not participate in the virtual courses of the Ministry of Health and the World Health Organization related to the corona virus. The mean and standard deviation for students' attitudes toward COVID-19 were generally 58.75 \pm 5.56 and their knowledge was $41.61 \pm 6.27$. The results showed that there was no significant relationship between attitude and demographic characteristics. Besides, there was a significant relationship between students' knowledge score and age $(\mathrm{p}<0.001)$, gender $(\mathrm{p}=0.002)$, degree $(\mathrm{p}<0.001)$, field of study $(\mathrm{p}<0.001)$ and semester under study ( $\mathrm{p}<0.001)$. However, there was no significant relationship between students' knowledge score, type of student residence, work experience in the coronary department and history of participating in virtual courses related to coronavirus.

Conclusion: According to the results of the current study, students of medical universities have an acceptable knowledge and attitude towards the disease. Despite the favorable scores in students' knowledge and attitudes, our knowledge about COVID-19 is increasing every day. On the other hand, students should have a higher awareness and attitude rather than other students due to their presence in hospitals to minimize the possibility of transmitting the disease to themselves and other people in the community. Therefore, it is necessary for the educational authorities of medical universities to design and implement programs to increase awareness and improve students' attitudes toward COVID-19.

Keywords: COVID-19, Knowledge, Attitude, Students

\section{Conflict of Interest: No}

How to Cite: Ranjbar Roghani A, Nemati R, Fathi Y, Sheikhnavaz Jahed S, Ajri Khamsloo F, Ajri Khamslou M. Knowledge and Attitude for Medical Students towards COVID-19. Iran Journal of Nursing. 2020; 33(126):44-57.

Received: 11 Jul 2020

Accepted: 10 Oct 2020 


\title{
آكاهى و نكرش دانشجويان علوم بزشكى نسبت به كويد-19
}

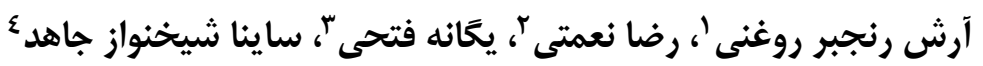

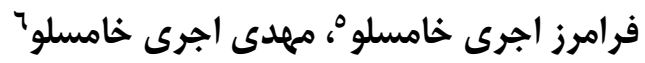

\begin{abstract}
جكيده

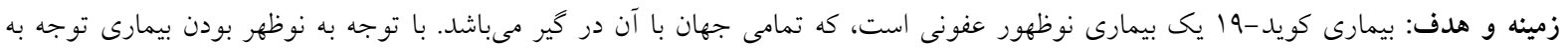

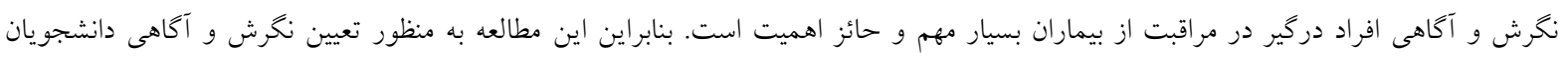

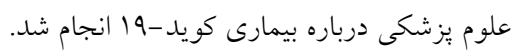

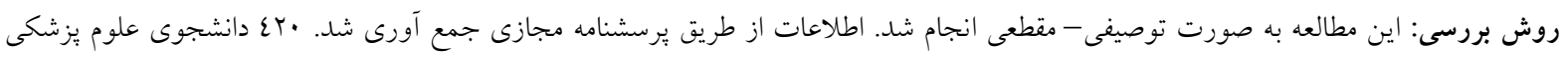

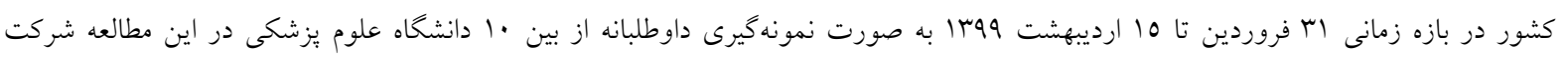

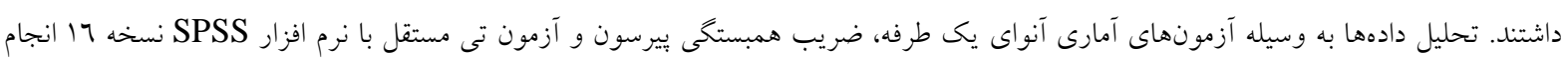
كرديد.
\end{abstract}

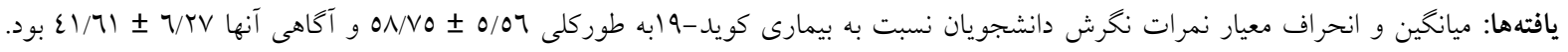

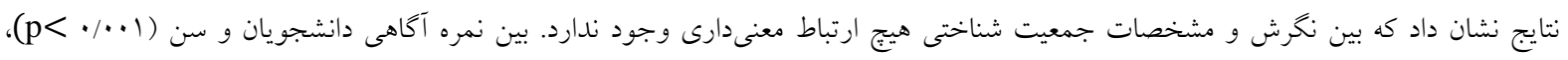

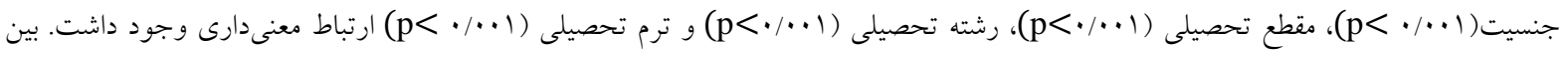

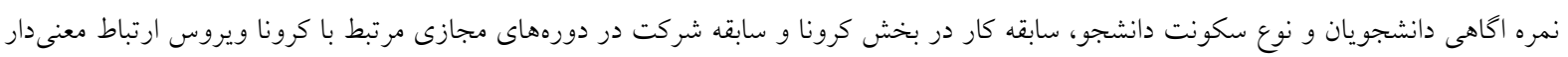
وجود نداشت.

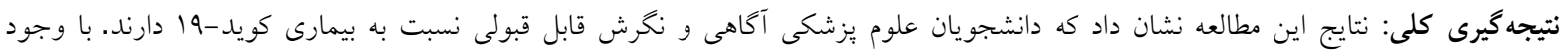

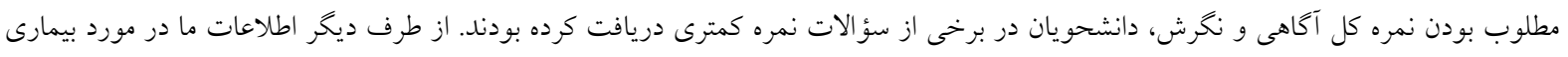

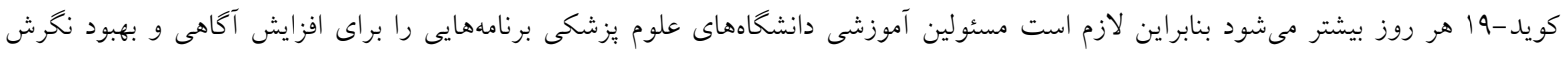
دانشجويان نسبت به بيمارىهاى كوويد-19 إطر احى و و اجرا نمايند. كليد وازهها: كويد-19 ا، آكاهى، نخرش، دانشجويان تعارض منافع: ندارد تاريخ دريافت: تاريخ يذيرش: 99/V/19

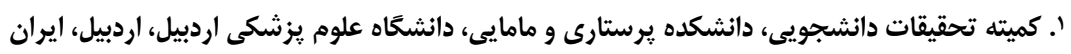

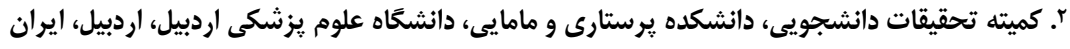

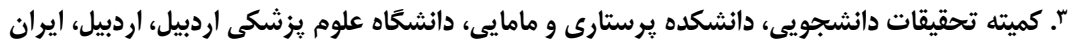

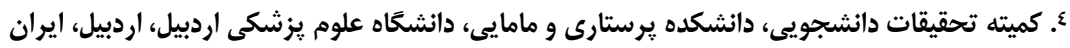

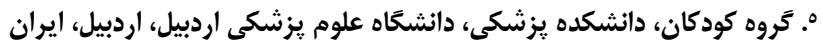

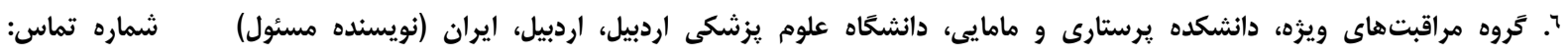


ارتباط معنى دار وجود دارد (1). همجنين در مطالعه انجام

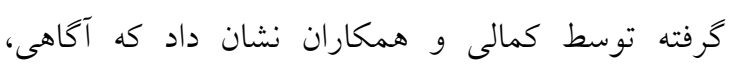

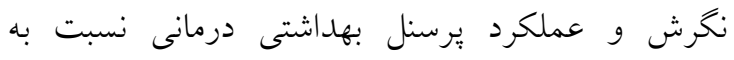

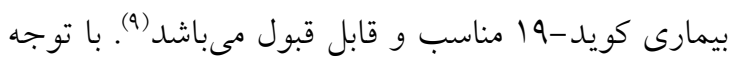

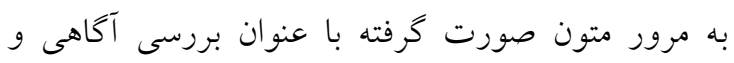

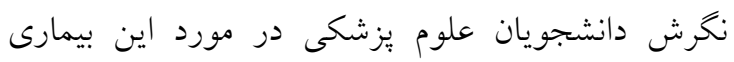

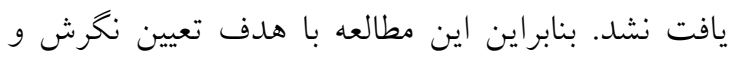

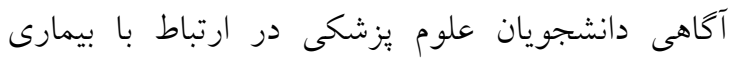

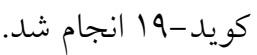

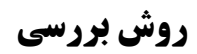

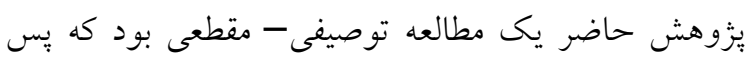

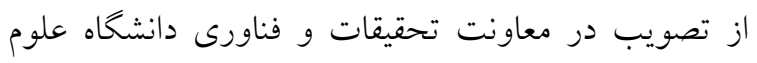

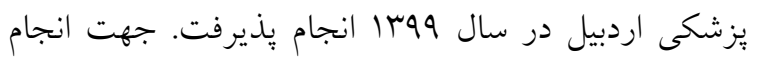
نمونهيرى از روش نمونه كيرى در دسترس و داوطلبانه

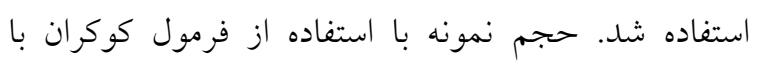

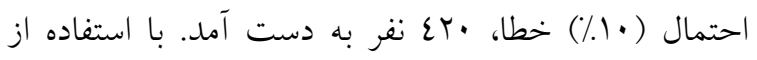

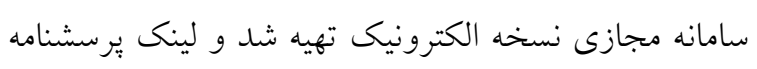
در كروههاى مختلف مجازى در اختيار دانشجويان دانشكاه

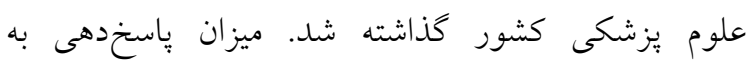

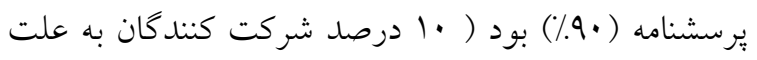

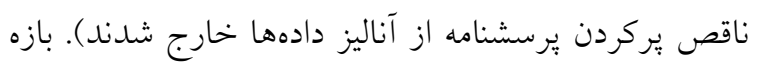

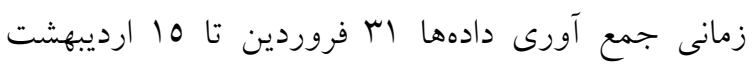

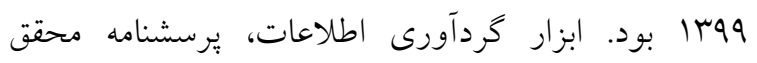
ساخته شامل سه بخش مشخصات جمعيت شناختى،

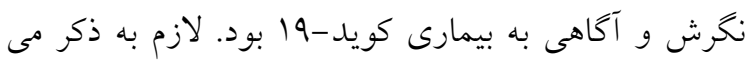
باشد اين يرسشنامه بعد از مرور متون موجود و همجنين

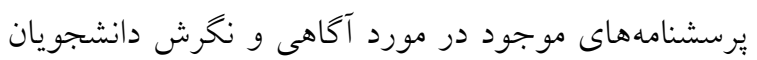
در مورد ساير بيمارىهاى تنفسى كه ناشى از ويروس كرونا مونس

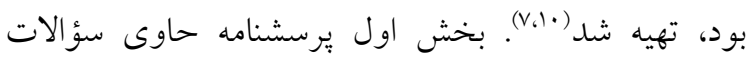

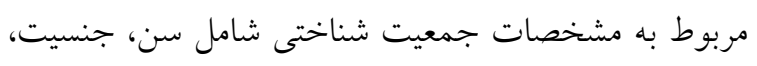
مقطع تحصيلى، رشته تحصيلى، ترم تحصيلى، نوع سكونت

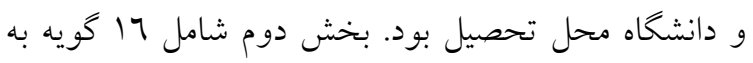

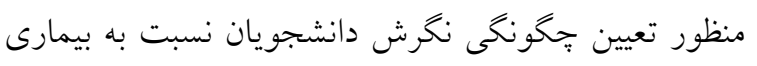

\section{مقدمه}

اواخر دسامبر سال 19 •T، شيوع يكى بيمارى از خانواده

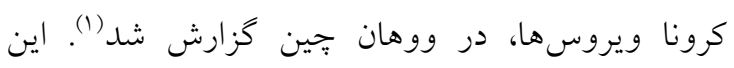

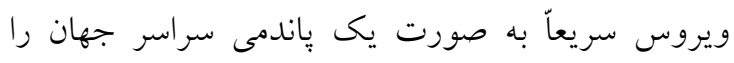
تحت تأثير خود قرار داد كه بر اساس اطلاعيههاى سازمان

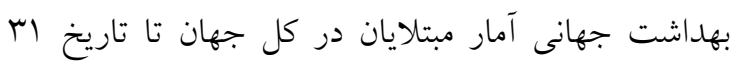

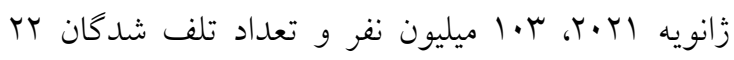

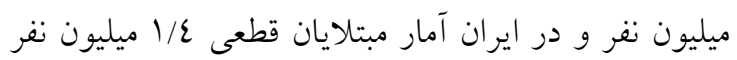

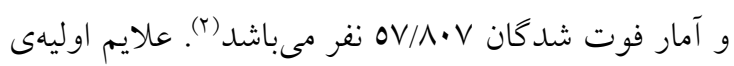

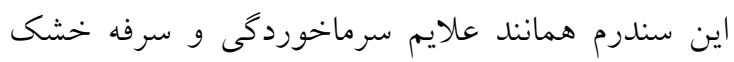

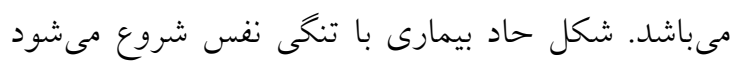

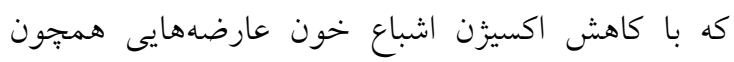

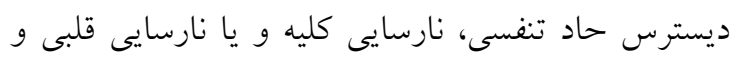

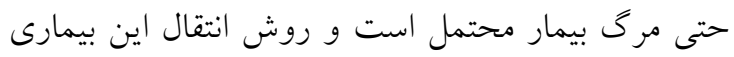

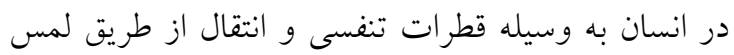

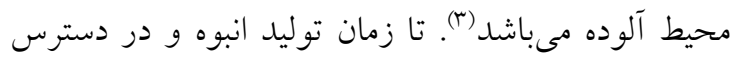
قرار كرفتن واكسن براى عموم مردم تنها روش كنترل آن فئن

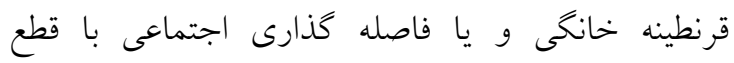

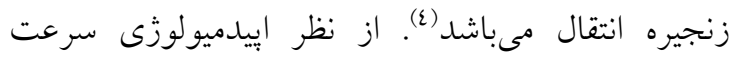
انتقال و شيوع اين بيمارى نسبت به بيمارىهاى واگيردار

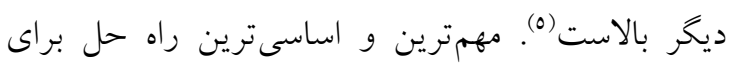

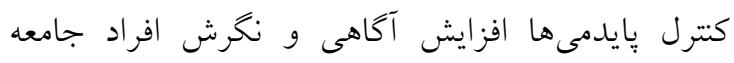

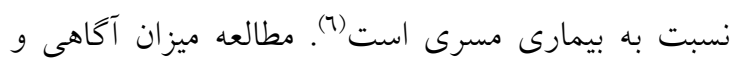

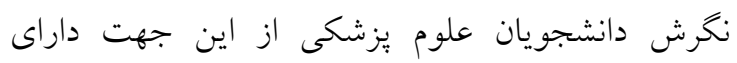

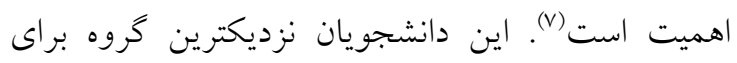

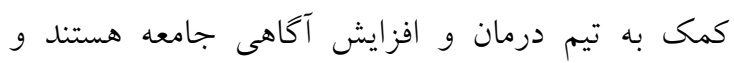
همجنين افراد در آيندهى نه تجندان دور بخشى از سيستم

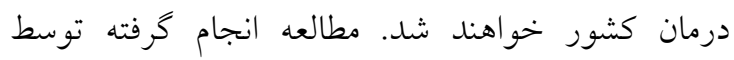
رحمانيان و همكاران بر روى بررسى آكاهى، نحرش و و عمكلرد دانشجويان علوم يزشكى جهرم نسيت به بيمارى كويد-19 نشان داد آكَاهى، نكخرش و عملكرد دانشجويان بالاتر از حد متوسط مىباشد. همجنين بين رشته

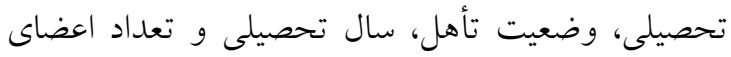
خانوار و عملكرد دانشجويان در مورد بيمارى كرونا 
اعضاى هيئت علمى) خواسته شد تا نظرات خود را در

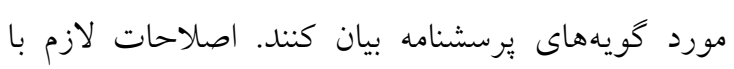
توجه نظر متخصصين در يرسشنامه اعمال شد. به منظور

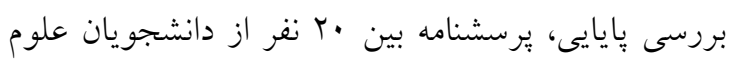

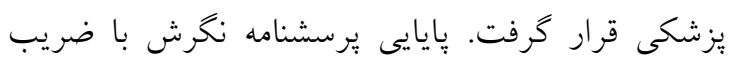

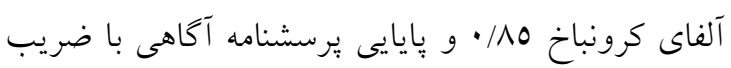
كودرريجاردسون A7/ • به دست امد.

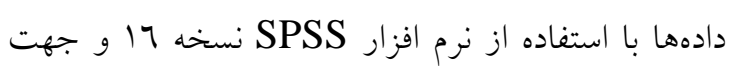

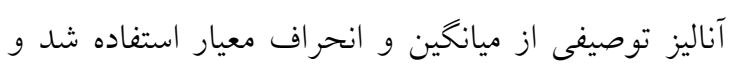

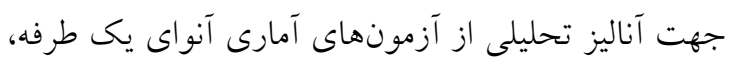

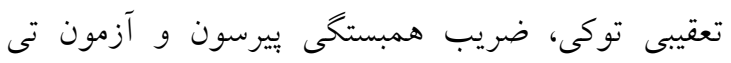

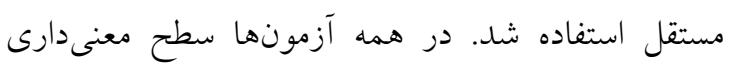
0٪• در نظر گرفته شد. مقاله حاضر بركرفته از طرح

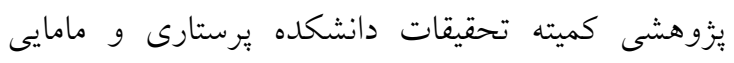

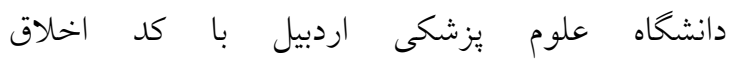

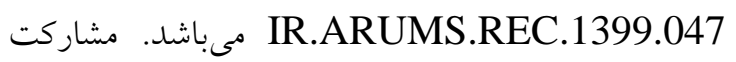
كند كان جهت تكميل يرسشنامه مجازى اختيار كامل

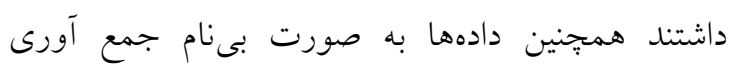

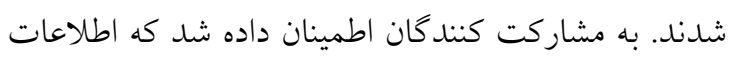
آنها محر مانه باقى خواهد ماند.

\section{يافتهها}

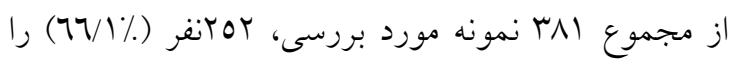

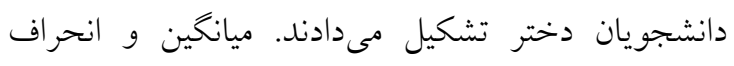

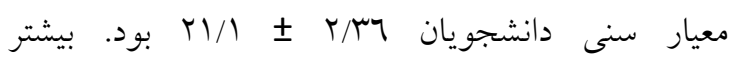

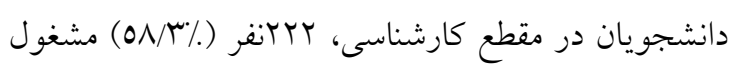

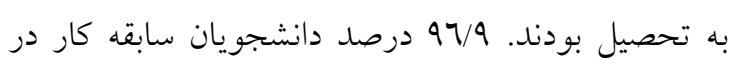

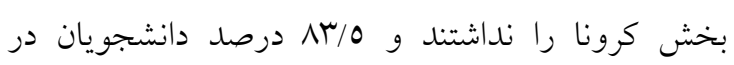

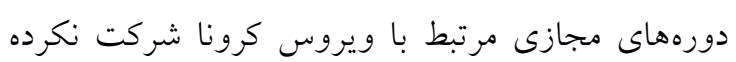
بودند (جدول شماره (1).
كويد-19 بر اساس مقياس ليكرت ينج گزينهاى (به صورت

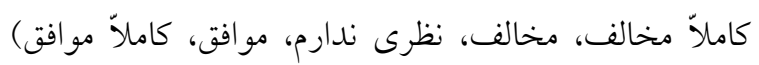

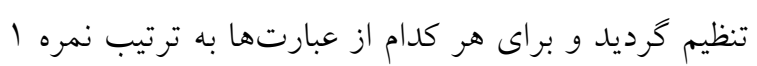

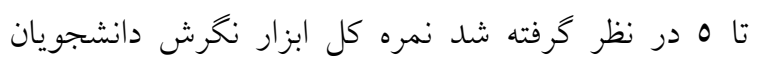

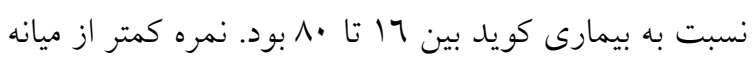

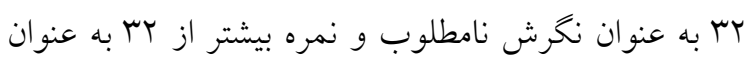

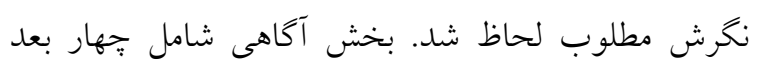

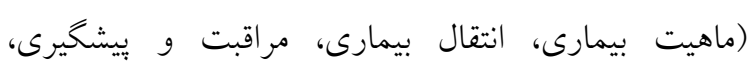

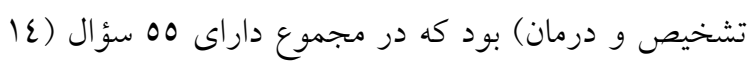

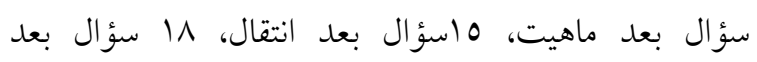

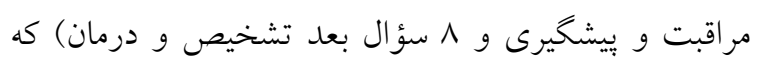

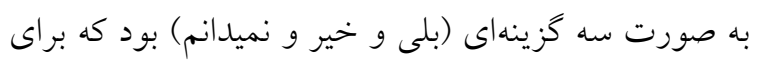
هر ياسخ صحيح يكى نمره مشبت در نظر كرفته شد. نمره

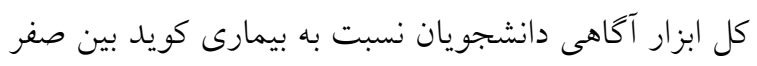

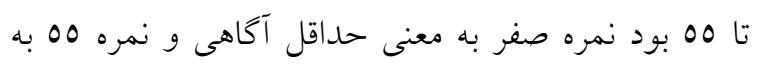

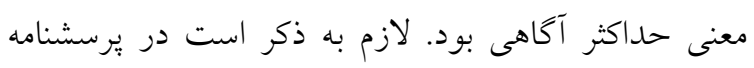

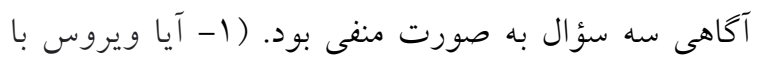

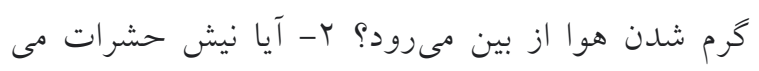

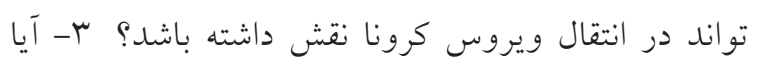

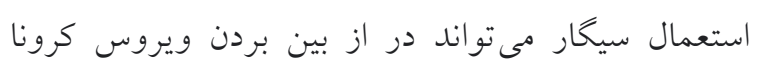

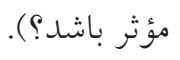
جهت تعيين روايى برسشنامه از روش روايى محتوايى و باتسو

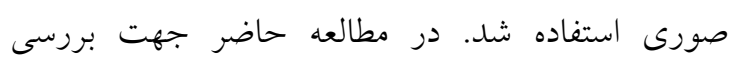

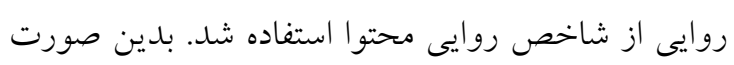

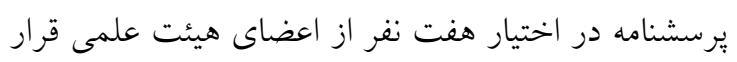

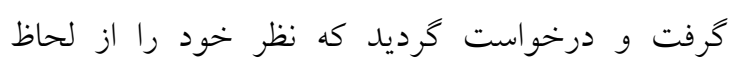
مرتبط بودن، واضح بودن، ساده بودن با استفاده از روش Waltz \& Bausell به كويههاى برسشنامه ابراز

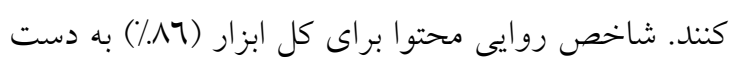

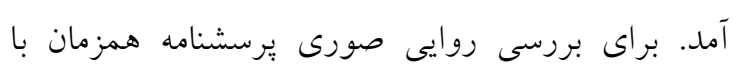

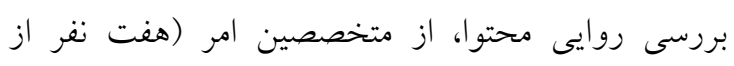


جدول شماره ا: توزيع فراوانى دانشجويان مورد مطالعه برحسب متغيرهاى جمعيت شناختى

\begin{tabular}{|c|c|c|c|}
\hline درصد & تعداد=|lی & متغير & \\
\hline $\mathbf{S D}=r / \mu r$ & Mean $=r \mid /$. & & سن \\
\hline$\varepsilon 7 / 0$ & IVV & $17 r^{\prime}$. & \\
\hline $01 / 1$ & 191 & rI_ro & \\
\hline$r / \varepsilon$ & ir & >ro & \\
\hline & & & جنسيت \\
\hline$m / q$ & $1 T 9$ & 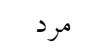 & \\
\hline $77 / 1$ & ror & زن ان & \\
\hline
\end{tabular}

\begin{tabular}{|c|c|c|}
\hline$\varepsilon / V$ & 11 & كاردانى \\
\hline$\Delta \wedge / \mu$ & TrY & كارشناسى \\
\hline$r / l$ & $\wedge$ & كارشناسى ارشد \\
\hline$r \varepsilon / q$ & (זו & دكتر اى حرفهاى \\
\hline
\end{tabular}

مقطع تحصيلى

\begin{tabular}{|c|c|c|}
\hline$r q / \varepsilon$ & $11 r$ & يزشكى \\
\hline$r / l$ & $\wedge$ & 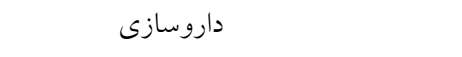 \\
\hline$\varepsilon / 0$ & IV & دندان يزشكى \\
\hline$M \pi / 9$ & $1 \% 9$ & يرستارى \\
\hline$r \cdot / r$ & 110 & ي بير ايزشكى \\
\hline & & ترم درحال تحصيل \\
\hline$V \backslash / 1$ & rVI & $1 \_\varepsilon$ \\
\hline$r \varepsilon / \varepsilon$ & 94 & o_ 1 \\
\hline$\varepsilon / 0$ & IV & $>\wedge$ \\
\hline & & دانشگاه علوم بزشكى در حال تحصيل \\
\hline $1 Y / 7$ & $\varepsilon \wedge$ & دانشگاه علوم يزشكى تهران \\
\hline $0 / Y 0$ & $r \cdot$ & دانشگاه علوم يزشكى ايران \\
\hline o/ro & r. & دانشگاه علوم يزشكى گيلان \\
\hline$V / r \varepsilon$ & rA & دانشگاه علوم يزشكى همدان \\
\hline$V \pi \varepsilon$ & rA & دانشگاه علوم يزشكى كرمانشاه \\
\hline$r 0 / 90$ & irv & دانشگاه علوم يزشكى اردبيل \\
\hline $0 / 01$ & Yl & دانشگاه علوم يزشكى بيرجند \\
\hline$V / \cdot \wedge$ & TV & دانشخاه علوم يزشكى لرستان \\
\hline$r / 9 \varepsilon$ & 10 & دانشگاه علوم يزشكى كُاباد \\
\hline$r / \pi r$ & $1 \cdot$ & دانشكاه علوم يزشكى كرمان \\
\hline \multirow[t]{3}{*}{$\mathrm{V} / \cdot \wedge$} & rV & دانشخاه علوم يزشكى تيريز \\
\hline & & 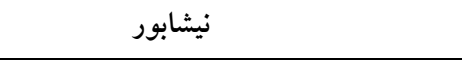 \\
\hline & & نوع سكونت \\
\hline$O V / O$ & $r 19$ & خانه شخصى \\
\hline$\sum T / 0$ & $17 r$ & خو ابشاهى \\
\hline
\end{tabular}

رشته تحصيلى 


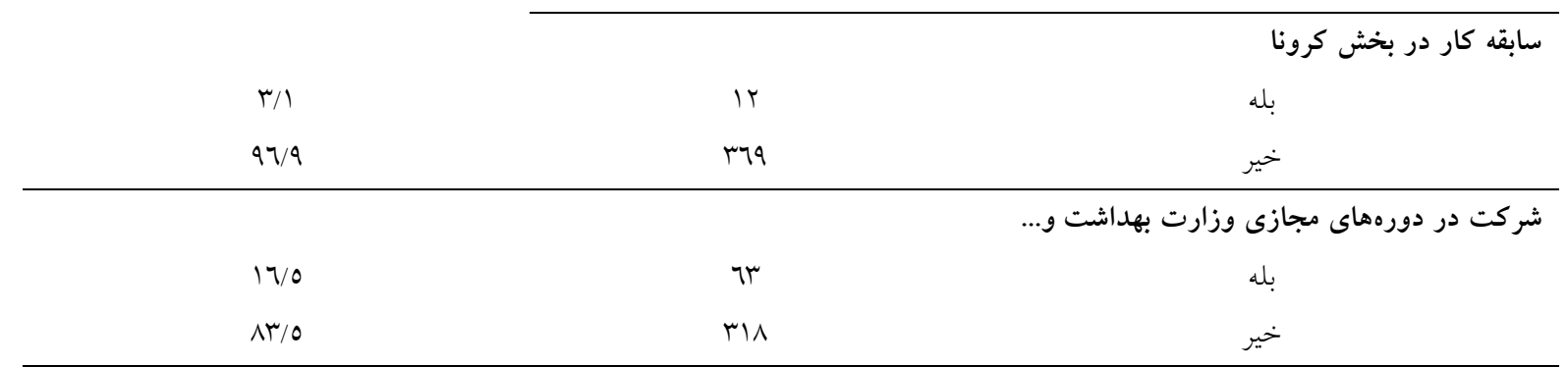

درمان مىدانستند و تنها T/7 إدصد دانشجويان معتقد بودند كه اين بيمارى غير قابل كنترل مىباشد.

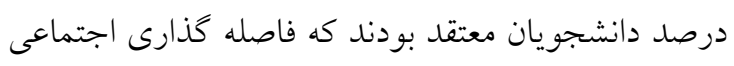
در كترل اين بيمارى مؤثر است. (جدول شماره Y).
ميانگين و انحراف معيار نمرات نخرش دانشجويان نسبت

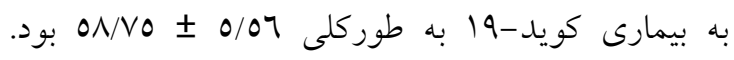

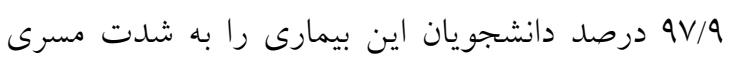

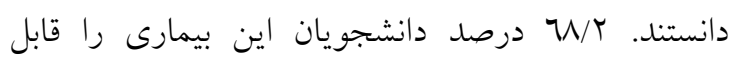

جدول شماره ז: توزيع فروانى باسخَّويى به سؤالات نغرش نسبت به بيمارى كوويد-19

\begin{tabular}{|c|c|c|c|c|c|}
\hline & & درصد & & & 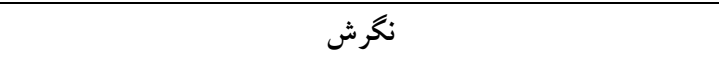 \\
\hline كاملاً مخالفم & 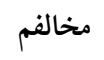 & نظرى ندارم & 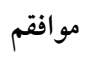 & كاملاً موافقم & \\
\hline · & $\cdot / r$ & $1 / 1$ & $r \varepsilon / \varepsilon$ & $V r / 0$ & اين بيمارى يك بيمارى به شدت مسرى است. \\
\hline $1 / 7$ & $11 / 1$ & $1 N / \varepsilon$ & $00 / 9$ & $1 r / r$ & بيمارى كرونا قابل درمان است. \\
\hline \multirow[t]{2}{*}{$\mathrm{V} / \mathrm{T}$} & $17 / 0$ & r7 & $r q / 9$ & 1. & وزارت بهداشت مىتواند شيوع ويروس COVID-19 \\
\hline & & & & & را كترل كند. \\
\hline \multirow[t]{2}{*}{$1 / 1$} & $\Lambda / 1$ & $1 V / 7$ & $07 / r$ & $17 / \mu$ & آموزش هاى وزارت بهداشت، براى محافظت در برابر \\
\hline & & & & & 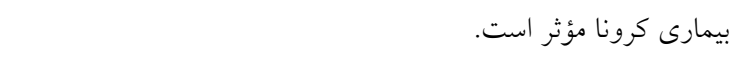 \\
\hline \multirow[t]{2}{*}{$\cdot / 0$} & $\cdot / r$ & $r / 7$ & rY/o & $v \cdot / 1$ & - بخذارد. \\
\hline & & & & & \\
\hline$\cdot$ & $\cdot / 0$ & $\cdot / 0$ & $r\urcorner / \wedge$ & $V T / T$ & اين بيمارى مى تواند سلامت خانوادهها را تحت تأثير قرار دهد. \\
\hline $\mid V / I$ & $\Upsilon \wedge / 9$ & 17 & ro/0 & $1 Y / 7$ & من از كار در بخش كرونا مىترسم. \\
\hline \multirow[t]{2}{*}{$r Y / 7$} & $r \varepsilon / 9$ & $1 \varepsilon / r$ & $r \cdot / r$ & N/1 & من در اين زمان از كار در بخشهاى غير كرونايى مى \\
\hline & & & & & 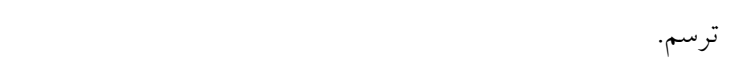 \\
\hline$\Lambda / 1$ & 1. & or & $1 / / 7$ & $11 / \pi$ & اين ويروس جهت بيوتروريسم ساخته شده است. \\
\hline $10 / 0$ & $0 \wedge / r$ & $1 Y / 7$ & $11 / 0$ & $r / 1$ & 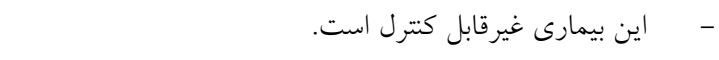 \\
\hline 1 & $1 / 7$ & $1 / 7$ & $r q / 1$ & $77 / \mathrm{V}$ & - تعطيلى مدارس و دانشگاهها در كترل شيوع بيمارى تأثير كذار \\
\hline · & $r / 9$ & $7 / 1$ & $\varepsilon \cdot / 9$ & $\varepsilon 9 / \mu$ & \multirow{3}{*}{ 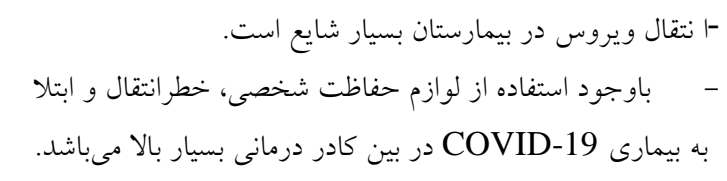 } \\
\hline \multirow[t]{2}{*}{ · } & $1 r / 9$ & $\mid r / \varepsilon$ & 0.11 & $r Y / 7$ & \\
\hline & & & & & \\
\hline$\cdot / \Lambda$ & $11 / 1$ & N/9 & or & $r\urcorner / 0$ & - - من از ابتلا خودم و اعضاى خانوادهام به بيمارى كرونا مى \\
\hline \multirow[t]{2}{*}{$r \cdot / v$} & $r \mathrm{r} / \mathrm{o}$ & $|r /|$ & $1 r / 9$ & $7 / 1$ & ترس از اين بيمارى باعث لطمه روحى و ايجاد \\
\hline & & & & & افسردكى در من شده است. \\
\hline$r / 1$ & $0 / 1$ & $\pi$ & $\varepsilon r$ & $\sum 1 / N$ & - ـ إصله كذارى اجتماعى در كنترل اين بيمارى مؤثر است. \\
\hline
\end{tabular}


مراقبت و بيشخيرى از بيمارى كويد-19 فقط 11/9 درصد دانشجويان از آسيب رسانى كلر به يوست و لزوم عدم استفاده از اين ماده براى ضد عفونى دست خبر داشتند، 00/1 درصد دانشجويان معتقد بودند كه بايد موارد مشكوك و احتمالى در اتاق ايزوله با فشار منفى بسترى شوند. در بعد تشخيص و درمان تنها سوصد دV دانشجويان مصرف داروى فسفات كلروكين را در بهبود شرايط بيمار مؤثر دانستند و Or/A درصد از دانشجويان CT scan و آزمايش CBC را آزمايش تشخيص كوريد نمى دانستند (جدول شماره ب).
ميانخين و انحراف معيار نمرات آكاهى دانشجويان نسبت

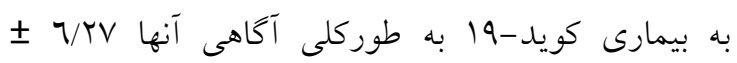

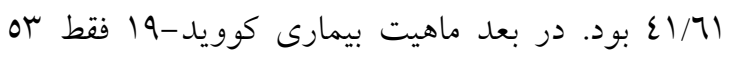
درصد از دانشجويان از دوره كمون ع الى ^ب روزه بيمارى خبر داشتند، •9 درصد از دانشجويان از عامل ايجاد كننده اين بيمارى آكاهى داشتند. در بعد انتقال

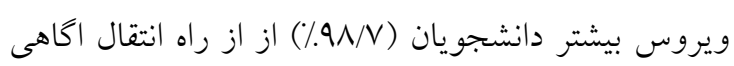
داشتند. ب/ آ درصد دانشجويان از عدم انتقال ويروس توسط حيوانات و ه درصد آنها از كسترش ويروس در در غذاهاى فريز شده و يخجالى اطلاع داشتند. در بعد

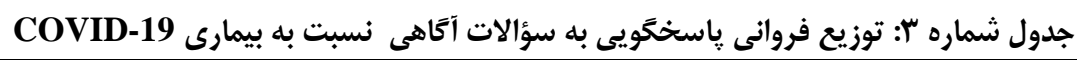

\begin{tabular}{|c|c|c|}
\hline \multicolumn{2}{|c|}{ 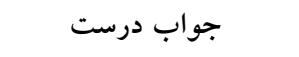 } & \multirow[b]{2}{*}{ آكاهى } \\
\hline \multirow{2}{*}{ تعداد كل } & درصد & \\
\hline & & COVID-19 بعد ا: ماهيت ويروس كرونا و بيمارى \\
\hline r々) & 9. & - عامل ايجاد كننده بيمارى Corona Virus، COVID-19 است. \\
\hline rV & $9 \Lambda / r$ & - علائم شايع بيمارى COVID-19 شامل تب، سرفه خشك و تنخى نفس مىباشد. \\
\hline$r \cdot r$ & $\vee 9 / \mu$ & - الكل ( •VI) مىتواند ويروس كرونا را از بين ببرد. \\
\hline TVV & $V Y / V$ & - كرماى بالا توانايى از بين بردن اين ويروس را دارد. \\
\hline$r \cdot \varepsilon$ & $O r / 0$ & - دوره كمون بيمارى COVID-19 مىتواند ع الى یץ روز باشد. \\
\hline \multirow[t]{2}{*}{ ro. } & $91 / 9$ & - ويروس COVID-19 مىتواند بر دستگاه تنفسى (بينى، كلو، ريه) اثر بحذارد و منجر به ذات الريه و بيمارى \\
\hline & & 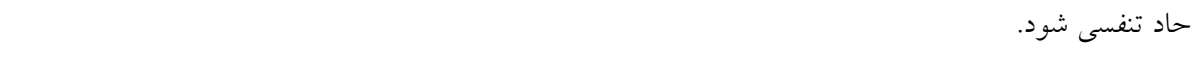 \\
\hline 194 & $0 . / \mathrm{V}$ & - ويروس با خرم شدن هوا از بين نمىرود. \\
\hline rıo & $\vee \varepsilon / \wedge$ & - ويروس COVID-19 در محيطهاى سرد و خشك مدت زمان بيشترى زنده مىماند. \\
\hline mat & 90 & - - ويروس مىتواند روى سطوح زنده بماند. \\
\hline$r \cdot v$ & $\wedge \cdot / 7$ & - بزرگسالان در معرض خطر ابتلاى بيشترى نسبت به كودكان هستند. \\
\hline rev & $91 / 1$ & - افراديكه سن 70 سال و بالاتر دارند، در معرض خطر بالاى ابتلا به بيمارى هستند. \\
\hline \multirow[t]{2}{*}{ mar } & $M N / r$ & - بييوند مغز استخوان يا اعضاى بدن، نقض ايمنى، استفاده طولانى مدت از كورتيكواستروئيدها و ساير داروهاى \\
\hline & & تضغيف كننده سيستم ايمنى بدن، خطر ابتلا به بيمارى كرونا را افزايش مىدهند. \\
\hline 190 & $01 / r$ & - افراديكه داراى جاقى شديد (BMI > • •ع) مياشند، خطر ابتلا به بيمارى COVID-19 بيشترى دارند. \\
\hline \multirow[t]{2}{*}{ ror } & $9 r / 9$ & - در افراد مبتلا به بيمارىهاى زمينهاى (ديابت، بيمارى كبدى، بيمارى مزمن كليوى، آسم متوسط تا شديد، ايدز، \\
\hline & & سرطان) خطر ابتلا به بيمارى COVID-19 بيشتر است. \\
\hline
\end{tabular}


rVT $9 \Lambda / \mathrm{T}$

$119 \quad r / \pi$

r7o 90/1

TVE $\quad V T / q$

ror $\quad 9 T / N$

ror

$\mu \cdot \tau$

rV

YNO VE/A

r7o 90/

rVE $\quad 9 / / T$

11. $\varepsilon V / T$

$r \varepsilon \varepsilon$

$9 \cdot \mu$

- ويروس مىتواند از طريق قطرات تنفسى حاصل از سرفه يا عطسه فرد مبتلا به بيمارى COVID-19 انتقال يابد. - حيوانات خانكى ناقل ويروس

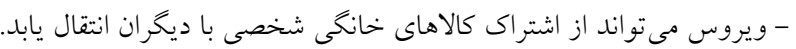

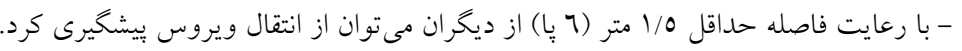

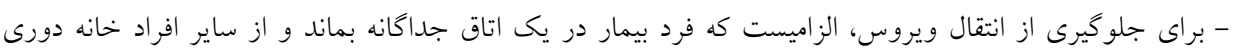

كند.

- شخصى كه داراى علائم خفيف بيمارى COVID-19 است بايد تا زمان وضوح علائم بالينى و نتايج منفى آزمايش PCR

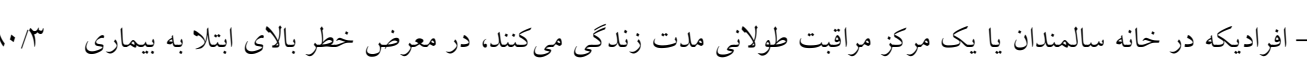
كرونا هستند. - در خانه ماندن (قرنطينه) در مناطقى كه شيوع بيمارى بالاست در بيشخيرى از ابتلا به بيمارى COVID-19 تأثير

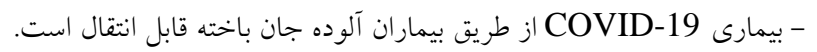
- اين بيمارى از طريق افرادى كه در معرض ابتلا بودهاند ولى بدون علادئ خاصى هستند، مى تو اند انتقال يابد.

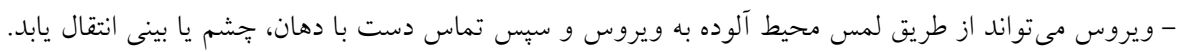
- ويروس با نيش حشرات انتقال نمى يابد.

\begin{tabular}{|c|c|c|}
\hline $7 \mathrm{~V}$ & $v \cdot / l$ & - ويروس مىتواند از طريق محصولات حيوانى مانند تخم مرغ و شير خام يا نيم يز منتقل شود. \\
\hline & & COVID-19 بعدץ: مراقبت و بيشخيرى از ويروس \\
\hline M & $\Lambda \mu / 0$ & - مى توان در صورت در دسترس نبودن آب و صابون، از يك ضدعفونى كننده حاوى الكل (حداقل •ج٪) استفاده كرد \\
\hline rVE & $91 / 4$ & - افراد مبتلا به بيمارى COVID-19 بايد از حمل و نقل عمومى اجتناب كنند. \\
\hline M & $\Lambda r / 0$ & - براى ويروس كرونا واكسن وجود ندارد. \\
\hline MIV & $\Lambda \mu / r$ & - استعمال سيگار نمىتواند در از بين بردن ويروس كرونا مؤثر باشد. \\
\hline$r \cdot r$ & $\vee 9 / 0$ & - مصرف آنتى بيوتيك در ازبين بردن ويروس كرونا نقش ندارد. \\
\hline$r \mu \varepsilon$ & $71 / \varepsilon$ & - خوردن سير نمىتواند از ابتلا به بيمارى كرونا جلو كيرى كند. \\
\hline 117 & $r \cdot / \varepsilon$ & - شستشوى مكرر راه هو ايى بينى با آب نمك نمىتواند در بيشخيرى از عفونتهاى تنفسى مؤثر باشد. \\
\hline VY & $11 / 9$ & - اسبرى كلر برروى يوست براى از بين بردن ويروس نمىتواند راه مناسبى باشد. \\
\hline $\operatorname{lvr}$ & $\varepsilon 0 / \varepsilon$ & - براى ضدعفونى كردن دست و يوست نمىتوان از لامٍ UV استفاده نمود. \\
\hline ror & $77 / \varepsilon$ & - دست خشى كنها در از بين بردن ويروس كرونا مؤثر نيستند. \\
\hline rir & $00 / 9$ & - حمام داغ نمى تواند بدن را در مقابل ابتلا به اين بيمارى محافظت كند. \\
\hline r. & $00 / 1$ & - موارد مشكوى و احتمالى مبتلا به كرونا ويروس بايد در اتاق ايزوله با فشار منفى بسترى شوند. \\
\hline rVr & $9 \vee / 9$ & - قبل از ماسك زدن و بعد از درآوردن آن بايد دستها مجدداً شست و شو شوند. \\
\hline$r \varepsilon$. & $19 / \mu$ & - استفاده از ماسك N95 در هنگام مراقبت از بيمار مبتلا به كرونا الزاميست. \\
\hline rVr & $9 \vee / 9$ & - سطوحى با لمس زياد مثل تلفن، كليد برق، دستخيره درب، صفحه گوشى لازم است روزانه ضدعفونى شوند. \\
\hline m77 & $97 / 1$ & - ضرورى است كه دستان خود را مكرراً در طول روز به مدت ·ب ثانيه با آب و صابون شست و شو داد. \\
\hline rV. & $v \cdot / q$ & - لباسهاى شخصى بيمار را نبايد با لباس ساير افراد شستشو داد. \\
\hline \multirow[t]{2}{*}{$r \cdot 0$} & $\Lambda \cdot / 1$ & - بهترين راه براى ييشخيرى ازبيمارى جلو كيرى از قرار گرفتن در معرض ويروس COVID-19 است. \\
\hline & & بعد ع: تشخيص و درمان ويروس COVID-19 \\
\hline$|\varepsilon|$ & rv & - داروى فسفات كلروكين در تسريع بهبودى بيماران كرونايى مؤثر است. \\
\hline
\end{tabular}




\begin{tabular}{|c|c|c|}
\hline rry & $10 / 7$ & - نوشيدن مايعات زياد همانند آب در روند بهبود بيمارى مؤثر است. \\
\hline ro9 & 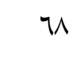 & - روش تشخيص بيمارى نمونه بردارى از ترشحات قسمت بالا و پايين راههاى هو ايى و تست PCR است. \\
\hline$r \cdot 1$ & or/A & CO خون، تست قطعى بيمارى CBC - \\
\hline m & $9 \varepsilon / \wedge$ & - تب سنجها نمىتواند ابتلا به ويروس كرونا را به حتم نشان دهند. \\
\hline rTE & 1० & - درمان قطعى براى اين بيمارى وجود ندارد. \\
\hline TAY & $\vee \varepsilon$ & - لازم نيست كه همه افراد تست ابتلا به ويروس را بدهند. \\
\hline
\end{tabular}

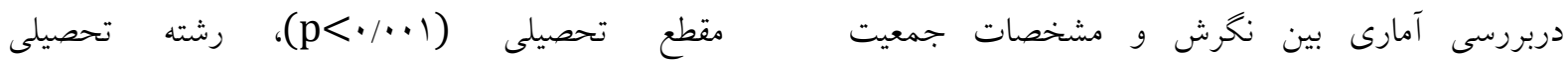

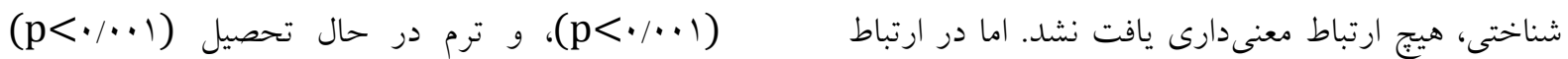

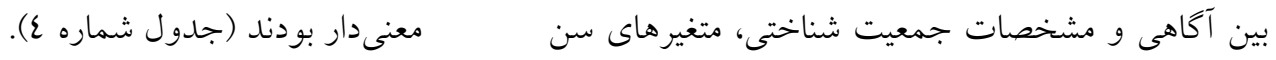

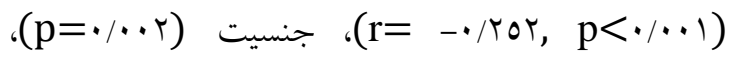

جدول شماره ع:نتايج بررسى نمرات نكَرش و آَاهى دانشجويان نسبت به بيمارى كويد- 19 بر حسب متغيرهاى جمعيت شناختى

\begin{tabular}{|c|c|c|c|c|}
\hline \multicolumn{2}{|c|}{ آكاهى } & \multicolumn{2}{|c|}{ 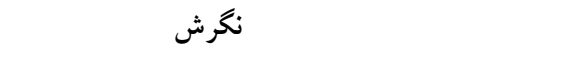 } & \multirow[b]{2}{*}{ متغير } \\
\hline سطح معنى دارى & ميانغين \ انحر اف معيار & سطح معنى دارى & ميانكين 土 انحراف معيار & \\
\hline$* \mathrm{p}<\cdot / . \cdot 1$ & $\{1 / 71 \pm 7 / T V$ & $\mathrm{p}=\cdot / \wedge \wedge$. & $0 / / V 0 \pm 0 / 07$ & +من \\
\hline \multirow[t]{2}{*}{$\mathrm{R}=-\cdot \cdot$ r ror } & & $\mathrm{R}=. / .79$ & & \\
\hline & & & & xجنسيت \\
\hline$* p=\cdot / \cdot r$ & $\varepsilon r / \cdot r \pm \varepsilon / q r$ & $\mathrm{p}=\cdot \pi r \uparrow$ & $O N / T O \pm O / T Y$ & مرد \\
\hline$d f=r q$. & $\varepsilon \cdot / 9 \cdot \pm \tau / v_{0}$ & $\mathrm{df}=r \vee q$ & $0 N / 90 \pm 0 / \Gamma_{0}$ & ز ت ان \\
\hline \multirow[t]{2}{*}{$\mathrm{T}=-\varepsilon / N \varepsilon$} & & $\mathrm{T}=-\cdot / \wedge 9 \mathrm{~T}$ & & \\
\hline & & & & \\
\hline$* \mathrm{p}<\bullet / \cdot \cdot 1$ & $r / 07 \pm 0 / 7 r$ & $\mathrm{p}=\cdot / 71 \mathrm{r}$ & $0 \Lambda / T V \pm T / \varepsilon$. & كاردانى \\
\hline$d f=r$ & $\varepsilon \cdot / T \pm \pm / V_{0}$ & $d f=r$ & $\Delta N / \varepsilon \varepsilon \pm 0 / V 7$ & كارشناسى \\
\hline \multirow[t]{3}{*}{$\mathrm{F}=1 r / v \varepsilon$} & $\left\{0 / T_{0} \pm N / r\right\}$ & $\mathrm{F}=\cdot / 71$ & $\left.\Delta N / M \pm \sum \varepsilon / \mu\right\rceil$ & كارشناسى ارشد \\
\hline & $\varepsilon \varepsilon / / r \pm \varepsilon / I V$ & & $09 / 77 \pm 0 / 19$ & دكتراى حرفه اى \\
\hline & & & & \#شته تحصيلى \\
\hline$* \mathrm{p}<\bullet / . \cdot 1$ & $\varepsilon \varepsilon / M T \pm \varepsilon / \cdot$ & $\mathrm{p}=\cdot / \wedge \cdot \wedge$ & $09 / \cdot \cdot \pm 0 / 11$ & يز تشكى \\
\hline $\mathrm{df}=\varepsilon$ & $\varepsilon \Gamma / \tau \Psi \pm \varepsilon / \mu \varepsilon$ & $\mathrm{df}=\varepsilon$ & $\left.7 \cdot / \Lambda \pm \sum / \mu\right\urcorner$ & 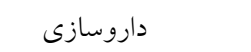 \\
\hline \multirow[t]{4}{*}{$F=q / 1 r$} & $\varepsilon r / \varepsilon \vee \pm T / \wedge 0$ & $F=1 / 91$ & $71 / 09 \pm 7 / \varepsilon$ & دندان يزشكى \\
\hline & $\varepsilon 1 / \cdot \varepsilon \pm 0 / M \Lambda$ & & $0 N / 11 \pm 0 / 7 \Lambda$ & يرستارى ي \\
\hline & $r q / \varepsilon \wedge \pm v / 00$ & & $0 / / 70 \pm 0 / V$ & بيرايزشكى \\
\hline & & & & ترم درحال تحصيل \\
\hline$* \mathrm{p}<\bullet / \cdot \cdot 1$ & $\varepsilon \cdot / \Lambda \cdot \pm \tau /\rceil \varepsilon$ & $\mathrm{p}=\cdot \mu \mathrm{\mu} \wedge$ & $01 / 77 \pm 0 / 70$ & $1 \_\varepsilon$ \\
\hline$d f=r$ & $\varepsilon r / \cdot r \pm \varepsilon / \varepsilon \varepsilon$ & $d f=r$ & $\Delta N / T \Lambda \pm O / \varepsilon \varepsilon$ & ○_^ \\
\hline \multirow[t]{2}{*}{$\mathrm{F}=\Lambda / 90$} & $\left.\sum \tau / V\right\urcorner \pm T / T V$ & $\mathrm{~F}=1 / \cdot 9$ & $O V / T \varepsilon \pm \varepsilon / \tau T$ & $>\wedge$ \\
\hline & & & & جنوع سكونت \\
\hline
\end{tabular}




\begin{tabular}{|c|c|c|c|c|}
\hline \multirow{3}{*}{$\begin{array}{l}\mathrm{p}=\cdot / q \cdot 1 \\
\mathrm{df}=r \vee q \\
\mathrm{~T}=\cdot / r r \mid\end{array}$} & \multirow{3}{*}{$\begin{array}{l}\varepsilon 1 / 0 \wedge \pm 7 / \varepsilon \vee \\
\varepsilon 1 / 77 \pm 7 / \cdots\end{array}$} & \multirow{3}{*}{$\begin{array}{c}\mathrm{p}=\cdot / \mathrm{rr} \\
\mathrm{df}=r \vee q \\
\mathrm{~T}=1 / \varepsilon\end{array}$} & \multirow{3}{*}{$\begin{array}{l}09 / \cdot 9 \pm 0 / 21 \\
0 N / T \Lambda \pm 0 / N O\end{array}$} & \multirow{3}{*}{ خانه شخصى } \\
\hline & & & & \\
\hline & & & & \\
\hline & & & & xسابقه كار در بخش كرونا \\
\hline $\mathrm{p}=\cdot /$ vqr & $\varepsilon r / \cdot \wedge \pm \varepsilon / 19$ & $\mathrm{p}=\cdot / \wedge \vee\urcorner$ & $O N / O \pm\{/ Y)$ & بله \\
\hline $\mathrm{df}=r \vee q$ & $\varepsilon 1 / 7 \cdot \pm \tau / \mu$ น & $\mathrm{df}=\mathrm{rvq}$ & $0 \wedge / \vee 7 \pm 0 / 71$ & خير \\
\hline \multirow[t]{2}{*}{$T=-9 / 29$} & & $\mathrm{~T}=-1 / 0 \mathrm{~V}$ & & \\
\hline & & & \multicolumn{2}{|c|}{ xشركت در دوره هاى مجازى وزارت بهداشت و... } \\
\hline $\mathrm{p}=\cdot / \uparrow \cdot \wedge$ & $\sum r / O r \pm O / r_{0}$ & $\mathrm{p}=\cdot / 79$ & $0 \wedge / 29 \pm 0 / 2 \wedge$ & بله \\
\hline $\mathrm{df}=\mathrm{rvq}$ & $\varepsilon 1 / \varepsilon r \pm \tau / \varepsilon r$ & $\mathrm{df}=r v q$ & $0 \wedge / 1 \cdot \pm 0 / 09$ & خير \\
\hline \multirow[t]{2}{*}{$\mathrm{T}=-1 / \Lambda \Lambda$} & & $T=-\varepsilon$ & & \\
\hline & $\{1 / T) \pm T / r V$ & & $01 / V 0 \pm 0 / 07$ & مجموع \\
\hline
\end{tabular}

(p=•/・1) داشتند. هميجنين نتايج آزمون توكى نشان داد كه دانشجويان ترم ع-1 به طور معنىدارى آكاهى

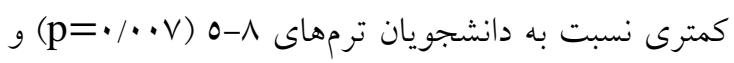
ترم هشت به بالا (1 (1) را داشتند (جدول شماره
نتايج آزمون تعقيبى Tamhane نشان داد كه دانشجويان دكترى حرفهاى به طور معنى دارى آكاهى بالاترى نسبت به دانشجويان دوره كارشناسى (1) ( ( $)$

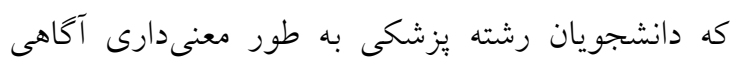
بيشترى نسبت به دانشجويان رشتهاى يرستارى

جدول شماره 0: نتايج تستهاى تعقيبى بر روى نمرات آتاهى دانشجويان نسبت به بيمارى كويد -19 بر حسب متغيرهاى جمعيت

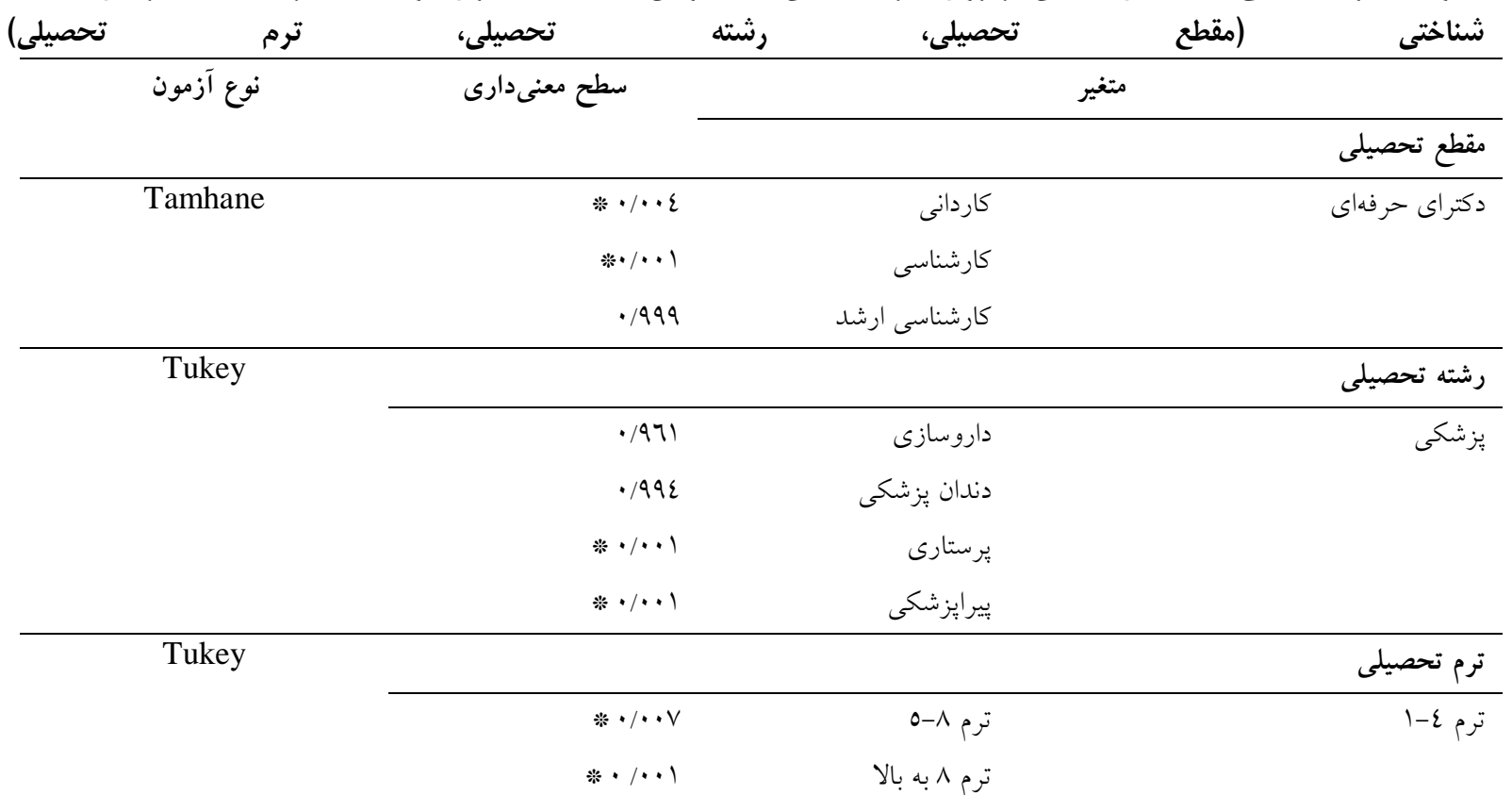


يروتكلهاى بهداشتى در فصول گرم اهميت دو جندان

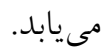
ـ ^/1/ درصد دانشجويان اطلاعى از بالا بودن خطر ابتلاى

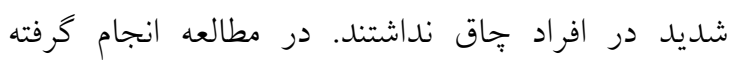
توسط Khasawneh و همكاران نيز دانشجويان علوم يزشكى آكاهى كافى نسبت به عوامل خطر ابتلا به موارد

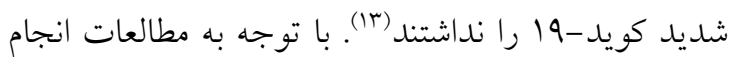
شده توسط Alberca و همكاران و Gao و همكاران جاقى به عنوان يك عامل مهم در ابتلا به موارد شديد ك هل

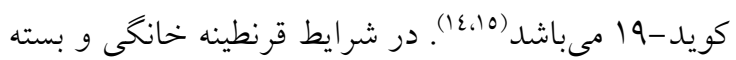
بودن باشخاههاى ورزشى و عدم تحرى افراد جامعه احتمال خاقى و افزايش وزن بالاتر رفته و خطر ابتلا به

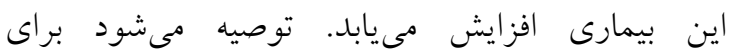
ييشخيرى از عوارض بى تحركى افراد نيم ساعت در روز در فضايى باز فعاليت ورزشى داشته باشند. در مطالعه حاضر بين نخرش و مشخصات جمعيت

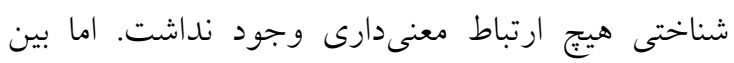

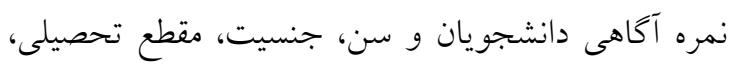
رشته تحصيلى و ترم در حال تحصيل ارتباط معنىدارى

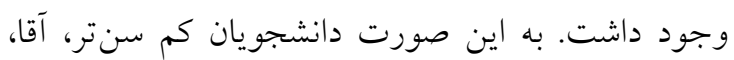
داراى تحصيلات ارشد، دكترى و ترمهاى بالاتر داراى اكاهى بيشترى نسبت به ساير دانشجويان بودند. در توجيه

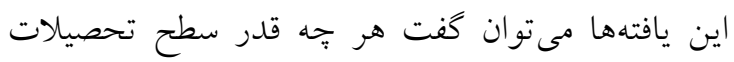

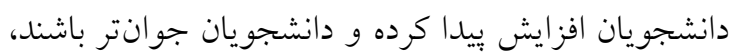

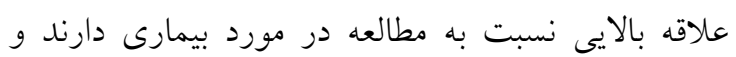
همين امر باعث شده كه نمره آكاهى اين دسته از

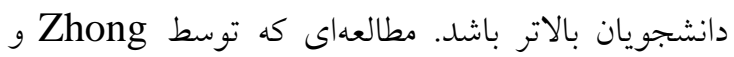
همكاران بر روى رزيدنتها در جين انجام شد نشان داد،

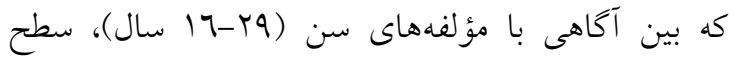
تحصيلات (كارشناسى به بالا) ارتباط معنىدار وجود دارد

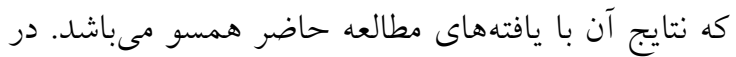
مطالعه Zhong و همكاران بين آخاهى با جنسيت (خانم)

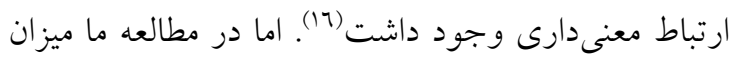
آكاهى در جنسيت مرد بيشتر از جنسيت زن بود. در درداط

\section{بحث و نتيجه}

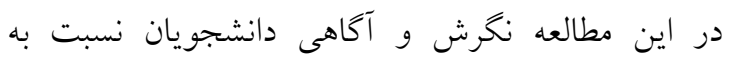
كويد-19 مطلوب ارزيابى شد كه هيايينتر از مطالعات

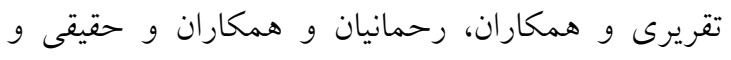

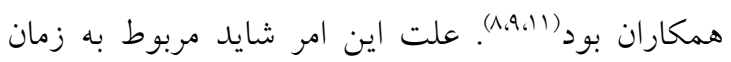
انجام نمونه كيرى بوده باشد در مطالعه حاضر زمان نمونه

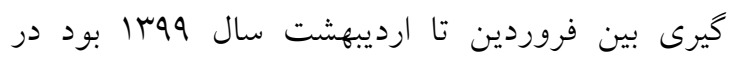

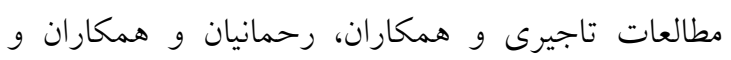

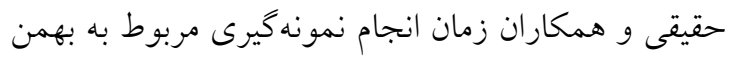

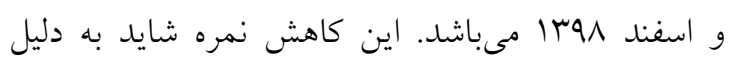

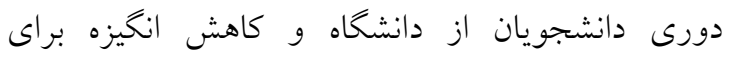
يادكيرى رخ داده باشد. در اين مطالعه در بعد نكرش بل بل درصد دانشجويان اذعان باند داشتند كه بيمارى كرونا قابل درمان مىباشد كه مغاير با نابن

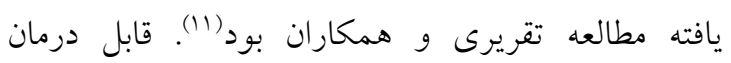

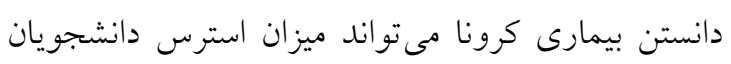

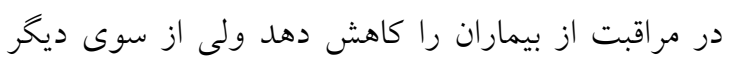

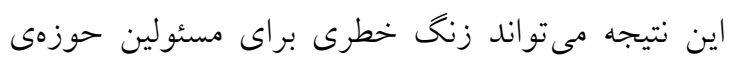

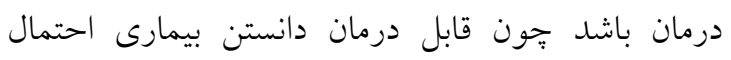
مراقبت نكردن از خود در مقابل بيمارى را بالاتر مىبرد و ودان

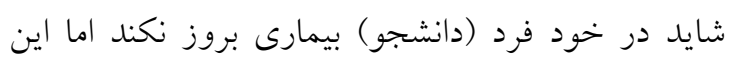

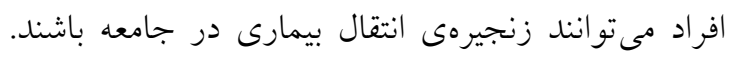

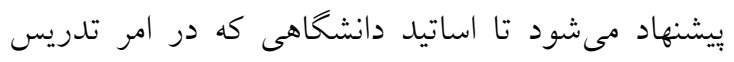

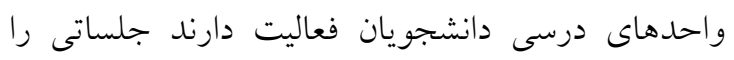

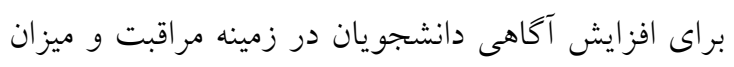
موفقيت در درمان و روش درمان اين بيمارى ارائه دهند. نيمى از دانشجويان معتقد بودند كه ويروس با كرم شدن هوا از بين مىرود كه همسو با مطالعه مر ادزاده و همكاران

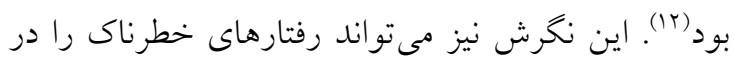

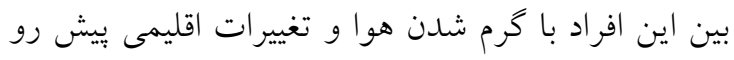

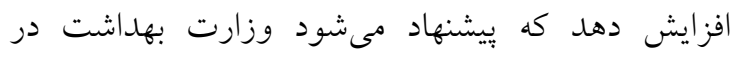
رسانههاى جمعى و شبكههاى اجتماعى در دسترس اطلاع رسانى كند. همجنين فرهنگ سازى در مورد رعايت 
بخش مهمى از جامعه يزشكى كشور نسبت به بيمارى

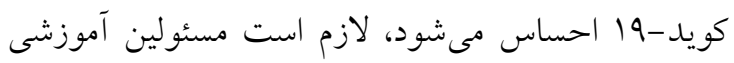

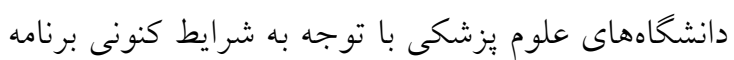

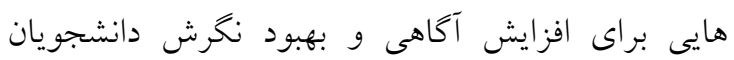
نسبت به بيمار كويد-19 طراحى و اجرا نمايند. مطالعه حاضر داراى محدوديتهايى مى باشد. اين مطالعه در سطح دانشجويان انجام شد و نتايج قابل تعميم به اين كروه از افراد جامعه است. محدوديت ديخر اين مطالعه

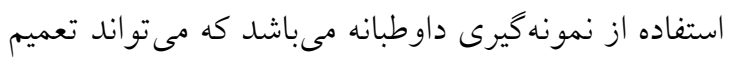

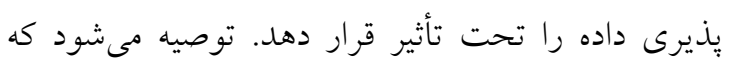

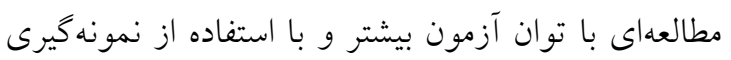

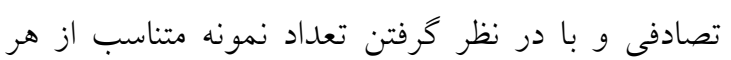
دانشخاه انجام گردد.

تعارض منافع: هيج كونه تعارض منافع توسط نويسندكان بيان نشده است.

\section{تقدير و تشكر}

مقاله حاضر برگرفته از طرح يُزوهشى كميته تحقيقات

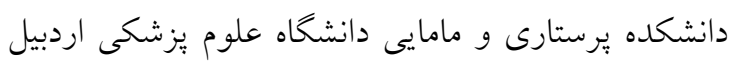

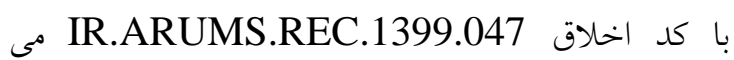
باشد. از تمامى عوامل حمايت كننده از اين يزوهش در دران

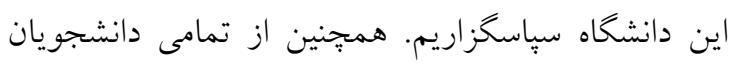

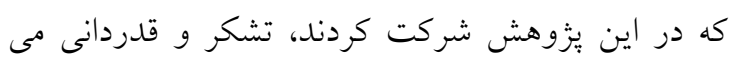
نماييم.
مطالعه Zhong و همكاران نخرش دانشجويان با مؤلفه هاى جنسيت، سن (99-17 سال) و سطح تحصيلات

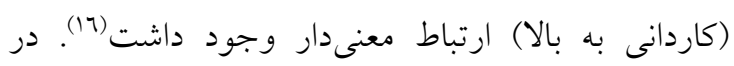
مطالعهاى كه بر روى آكاهى و نغرش كاركنان مراكز بهداشتى درمانى نسبت به بيمارى كوويد-19 در كشور

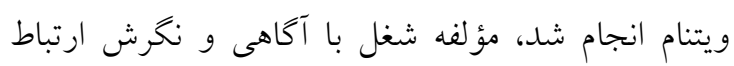

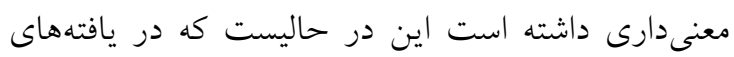

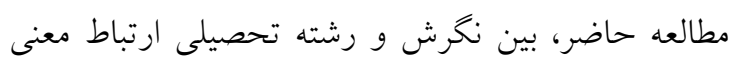

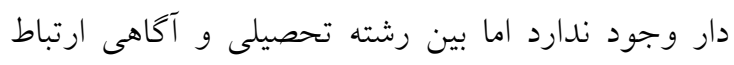

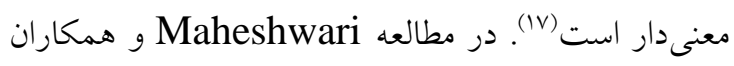

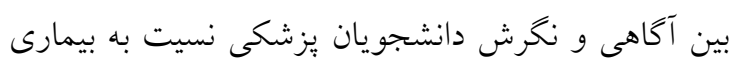

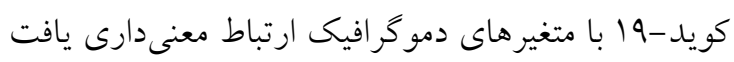

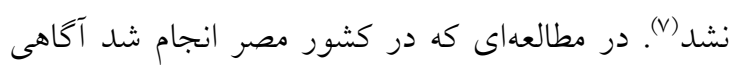
با مؤلفهاى سن و تحصيلات دانشگاهى ارتباط معنى دار

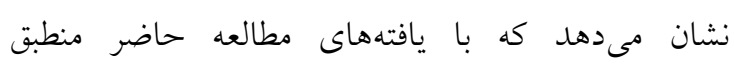
مى باشد (11). با توجه به شرايط و نحوه آموزش يزشكى و و ميزان دركيرى با بيمارى كويد-19 در كشورهاى مختلف ميزان

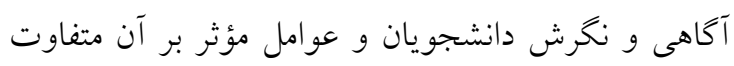

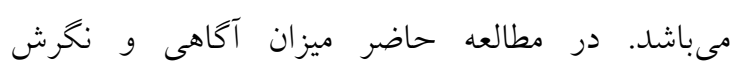
دانشجويان در حد قابل قبول بود اما در برخى از سؤالات

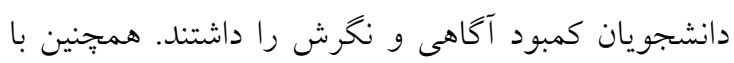

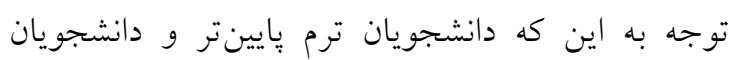

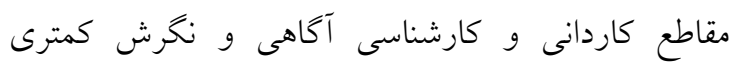

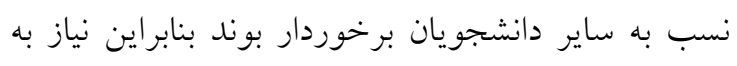
افزايش آكاهى و نحرش اين دسته از دانشجويان به عنوان

\section{References}

1. Huang C, Wang Y, Li X, Ren L, Zhao J, Hu Y, Zhang L, Fan G, Xu J, Gu X, Cheng Z. Clinical features of patients infected with 2019 novel coronavirus in Wuhan, China. The lancet. 2020;395(10223):497-506.

2. World Health Organization. Novel Coronavirus ( 2019-nCoV): situation report, 3. Geneva: WHO, 2020 2020-02-08.

3. Adhikari SP, Meng S, Wu YJ, Mao YP, Ye RX, Wang QZ, Sun C, Sylvia S, Rozelle S, Raat H, Zhou H. Epidemiology, causes, clinical manifestation and diagnosis, prevention and control of coronavirus disease (COVID-19) during the early outbreak period: a scoping review. Infec Dis Pover. 2020;9(1):1-12. 
4. Xu Z, Shi L, Wang Y, Zhang J, Huang L, Zhang C, Liu S, Zhao P, Liu H, Zhu L, Tai Y. Pathological findings of COVID-19 associated with acute respiratory distress syndrome. Lancet Respir Med. 2020;8(4):420-2.

5. Chiyomaru K, Takemoto K. Global COVID-19 transmission rate is influenced by precipitation seasonality and the speed of climate temperature warming. medRxiv. 2020 Jan 1.

6. Yakar B, Kaygusuz TÖ, Pirincci E, Önalan E, Ertekin YH. Knowledge, attitude and anxiety of medical students about the current COVID-19 outbreak in Turkey. Fami Pract Palliat Care. 2020;5(2):36-44.

7. Maheshwari S, Gupta PK, Sinha R, Rawat P. Knowledge, attitude, and practice towards coronavirus disease 2019 (COVID-19) among medical students: a cross-sectional study. J Acute Dis. 2020;9(3):100.

8. Rahmanian M, Dorodchi A, Zarenezhad M, Hatami N, Javdani F, Kalani N. Knowledge, Attitude and Practice of Students of Jahrom University of medical sciences to the new coronavirus (Covid-19). Medical Journal of Mashhad University of Medical Sciences. 2020;63(3):2359-69. [Persian]

9. Kamali Haghighi F, Kouhi P, Amini M, Mohammadkarimi V, Sepehrpoor M, Hosseini SA, Moosavi M, Sadeghi Boogar S. Knowledge, Attitude, and Practice Toward COVID-19 Among Healthcare Workers in Shiraz, Iran. Shiraz E-Medical Journal. 2020;21(12). [Persian]

10. Abdollahi M, Ghahramanian A, Shahbazi S, Rezaei F, Naghili B, Asghari-Jafarabadi M. Developing a questionnaire to assess Iranian nurses' knowledge of and attitude to Middle East respiratory syndrome. East Mediterranean Health J. 2020;26(5). [Persian]

11. Taghrir MH, Borazjani R, Shiraly R. COVID-19 and Iranian medical students; a survey on their related-knowledge, preventive behaviors and risk perception. Arch Iranian Med. 2020;23(4):249-54. [Persian]

12. Moradzadeh R, Nazari J, Shamsi M, Amini S. Knowledge, Attitudes, and Practices Toward Coronavirus Disease 2019 in the Central Area of Iran: A Population-Based Study. Frontiers in public health. 2020;8:862. [Persian]

13. Khasawneh AI, Humeidan AA, Alsulaiman JW, Bloukh S, Ramadan M, Al-Shatanawi TN, Awad HH, Hijazi WY, Al-Kammash KR, Obeidat N, Saleh T. Medical students and COVID19: Knowledge, attitudes, and precautionary measures. A descriptive study from Jordan. Frontiers in public health. 2020;8.

14. Alberca RW, Oliveira LD, Branco AC, Pereira NZ, Sato MN. Obesity as a risk factor for COVID-19: an overview. Crit Rev Food Sci Nutrit. 2020;13:1-5.

15. Gao F, Zheng KI, Wang XB, Sun QF, Pan KH, Wang TY, Chen YP, Targher G, Byrne CD, George J, Zheng MH. Obesity is a risk factor for greater COVID-19 severity. Diabetes care. 2020;43(7):e72-4.

16. Zhong BL, Luo W, Li HM, Zhang QQ, Liu XG, Li WT, Li Y. Knowledge, attitudes, and practices towards COVID-19 among Chinese residents during the rapid rise period of the COVID-19 outbreak: a quick online cross-sectional survey. Int J Biolog Sci. 2020;16(10):1745.

17. Huynh G, Nguyen TN, Vo KN, Pham LA. Knowledge and attitude toward COVID-19 among healthcare workers at District 2 Hospital, Ho Chi Minh City. Asian Pacific J Trop Med. 2020;13(6):260.

18. Abdelhafiz AS, Mohammed Z, Ibrahim ME, Ziady HH, Alorabi M, Ayyad M, Sultan EA. Knowledge, perceptions, and attitude of Egyptians towards the novel coronavirus disease (COVID-19). J Commun Health. 2020;45(5):881-90. 